\title{
THE ALIGNMENT BETWEEN EFFECTIVE PEOPLE MANAGEMENT, BUSINESS STRATEGY AND ORGANISATIONAL PERFORMANCE IN THE BANKING AND INSURANCE SECTOR
}

\author{
RUWAYNE KOCK \\ Department of Human Resource Management \\ Rand Afrikaans University \\ GERT ROODT \\ Department of Human Resource Management \\ Rand Afrikaans University \\ THEO H. VELDSMAN \\ People Effectiveness Consulting Group \\ CS Holdings
}

\begin{abstract}
The aim of the study was to determine the nature of the alignment between people management effectiveness, business strategy and organisational performance within the banking and insurance sector in South Africa. From the field study, it was evident that the majority of the participating companies fell short of people management best practices and were therefore unable to support their business strategies, which were in line with best practices. The organisational performance data was insufficient to determine the nature of the alignment between organisational performance, people management, and business strategy. The South African banking and insurance industry needs to realign their people management component to support the appropriate business strategy and to produce a desired level of organisational performance. A limitation of this study was the small sample size, which may have had some effect on the interpretation of the results. However, the sample represents a significant proportion of the South African banking and insurance sector. Although the magnitude and the direction of the relationships are still unclear, the opportunity exists for further longitudinal research.
\end{abstract}

\section{OPSOMMING}

Die doel van die studie was om die onderlinge verhouding tussen mensbestuursdoeltreffendheid, besigheidstrategie en organisasieresultate binne die Suid-Afrikaanse bank- en versekeringsektor te ondersoek. Die studie het duidelik gewys dat toonaangewende bestuurspraktyke by die meerderheid van die deelnemende organisasies ontbreek. Die mensbestuur was nie in staat om die besigheidstrategieë te ondersteun nie wat wel met wêreldwye beste praktyke ooreenstem. Inligting oor organisasieresultate was onvoldoende om enige afleiding te maak. Mensbestuur in die Suid-Afrikaanse bank- en versekeringsektor moet met die besigheidstrategie belyn word om die verwagte organisasieresultate te lewer. Die relatiewe klein steekproefgrootte was ' $n$ tekortkoming in die studie wat die vertolking van die resultate wesenlik bemoeilik. Die steekproefgrootte verteenwoordig egter 'n hoë persentasie van die Suid-Afrikaanse bank- en versekeringsektor. Alhoewel die omvang en sterkte van die onderlinge verhoudinge nog onduidelik is, is die potensiaal vir verdere navorsing wenslik.

In spite of a growing body of evidence to support the enormous financial performance obtained through effective people management, organisations are still moving in the opposite direction by utilising practices that are contrary to what is known regarding sound people management (Huselid, 1995; Huselid, Jackson \& Schuler, 1997; Templer \& Hofmeyer, 1989; Pfeffer, 1998). Notwithstanding the positive findings of effective people management, companies continue to pursuit restructuring and retrenchments as a means to increase organisational effectiveness and decrease expenses. This is very often the detriment to sound people management.

Previous international empirical studies have consistently found a significant relationship between people management and organisational performance (Auther, 1994; Becker \& Gerhart, 1996; Delery \& Doty, 1996; Haynes \& Fryer, 2000; Huselid, 1995; Huselid et al., 1997; Pfeffer, 1998; Welbourne \& Andrews, 1996; and Youndt, Snell, Dean \& Lepak, 1996). However, there appears to be little understanding of the magnitude and the direction of the relationship (Borucki, 1989), or the process to realise improved organisational performance through effective people management (Huselid et al., 1997). The study by Veldsman, Van der Linde and Conidaris (1998) found that the people management contribution to the success of South African companies

Requests for copies should be addressed to: $R$ Kock, Department of Human

Resource Management, RAU, PO Box 524, Aukland Park, 2006 was poor and needed to be reviewed. The study showed that the people management component in South African organisations was unable to support the business strategy in order to leverage strong organisational performance. It would thus appear that there was a misalignment between people management components and business goals in South African organisations.

The financial service sector is one of fastest growing sectors both internationally and in South Africa. In the 1998 World Competitiveness Report, the South African banking sector ranked thirteenth out of 53 nations (The South African Banking Review, 1998). In order to remain competitive, financial services firms in the United States, Canada, Latin America, Australia, South Africa and Asia Pacific are creating business strategies, products, structures and alliances that identify these firms more broadly as financial services companies (Van Gorp, Hall, Keene, Holden, \& Soh, 1997). The traditional distinctions between banks, insurance companies and brokerage firms are falling away as all compete for the same assets with increasingly similar products and services. Technology, deregulation and globalisation are causing a revolution in the financial services industry, whilst mergers and consolidations are reshaping the industry nationally and worldwide (South African Banking Review, 1999). These trends are evident in the South African financial services sector. 
International research in the banking industry has arrived at conclusions that support the significant relationship between better people management (customer services), business strategy and organisational performance (Delery \& Doty, 1996; Schneider \& Bowen, 1985; Schmit \& Allscheid, 1995). However, the findings by Schmit \& Allscheid, (1995) found a less consistent relationship between the business strategies and customer service (people). There is a need to further investigate the alignment between people management, business strategy and organisational performance to better understand the value-add of people. For these reasons, the broad aim of this study is to determine the alignment between people management effectiveness, business strategy and organisational performance within the banking and insurance sector in South Africa.

\section{People management: a conceptual model}

The study by Veldsman et al. (1998) provides a conceptual model (see Figure 1) to evaluate people management effectiveness in organisations. This model was used as a guideline to analyse people management effectiveness in this study.

According to the above conceptual model of people management (see Figure 1), the business strategy represents the setting within which the company's people management has to unfold; alignment refers to the consistency between the business strategy and the strategic people intent, people policies and practices of the company; the organisation's strategic people intent consists of the strategic people issues and priorities pursued; its people philosophy; the psychosocial contract reflecting the basic relationship between the organisation and its members; and the profile of its people; the people management policy and practices represent the policy choices and interventions adopted by the organisation to unleash the contribution of its people; the delivery process represents the actualisation of the strategic people intent, and the execution of the people policies and practices; and the outcomes, show the result of all of the aforementioned. The people management conceptual framework depicted in Figure 1 encompasses an integrated and systematic approach to people management. The term people management was used interchangeably with human resource management in this report.

A shortcoming of the Veldsman et al. (1998) study was the inability to measure the organisational performance (i.e. performance, quality of life, and the people value-add), because of the absence of comparable data. The study by Dyer and Reeves
(1995) was used to expand on the Veldsman et al. (1998) definition of organisational performance. According to Dyer and Reeves' (1995) definition, organisational performance consists of human resource outcomes (i.e. absenteeism; turnover; individual and group performance), organisational outcomes (productivity, quality and service), and financial outcomes (return on invested capital or return on asset and stock value or shareholder return). For the purpose of this study, organisational performance was defined in terms of the aforementioned three categories, i.e. financial, organisational and people management performance measurements.

According to Drago (1990) common financial indicators include: sales growth, return on investment (ROI), return on sales, return on equity (ROE), and earnings per share. In more recent research by Delery and Doty (1996), return on average assets (ROA) and return on equity (ROE) were used as financial measures in the banking industry. These financial measures support the measurements used in previous research (Borucki, 1989; Caliguiri \& Stroh, 1995; Dyer \& Reeves, 1995). Huselid et al. (1997) argues that the accounting-based profitability indicators was subject to numerous biases not presented in market-based measures, which are generally considered to be a more accurate reflection of a firm's financial health. For these reasons, the financial indicators of this study consisted of efficiency ratios, profits, return on assets, total assets, return on equity, capacity adequacy ratios, and advanced growth.

According to Dyer and Reeve (1995) organisational outcome measurements included productivity, quality and service. Huselid et al. (1997) defined employee productivity as the net sales (revenue) per employee. This definition was consistent with prior empirical work and tends to reflect employees' efforts (Auther, 1994; Delery \& Doty, 1996; Huselid, 1995; Huselid et al., 1997). However Huselid et al. (1997) considered the productivity indicator as an incomplete measure of a firm's overall profitability and therefore needed to be considered with other financial measurements. Instead of productivity indicators, Delany \& Huselid (1996) chose perceptual measures of the organisations' performance in their study. They selected perceived organisational performance such as product quality, customer satisfaction and new product development. Although perceptual data introduces limitations through increased measurement error and the potential for mono-method bias, it was not unprecedented to use such measures (Delany \& Huselid, 1995). For the purpose of this study organisational outcomes consisted of service and product quality, customer satisfaction and new product development.

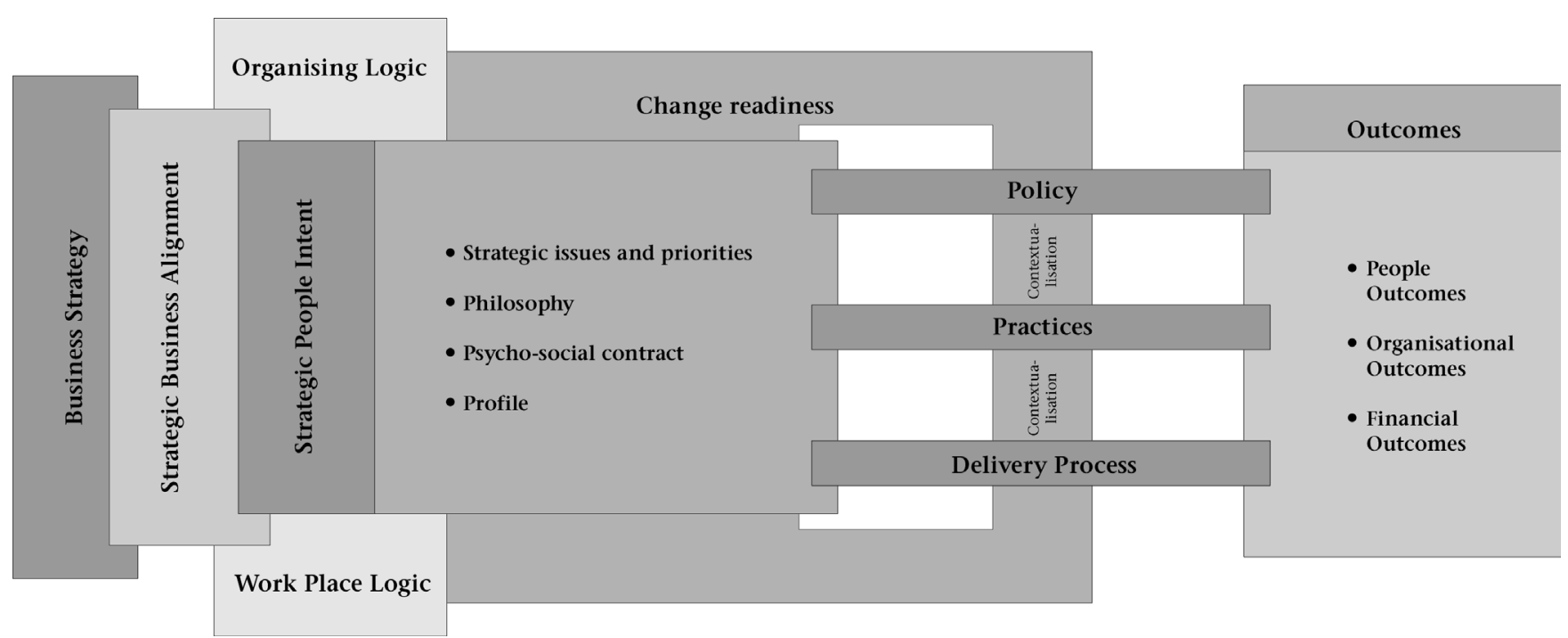

Figure 1: A conceptual model of people management in organisations 
The Saratoga report (1997) was used to establish the appropriate people management key performance indicators (KPI). The key performance indicators (KPI) demonstrated the value-add of people management in organisations. For the purpose of this study people management outcomes consisted of average profit per employee; average revenue per total employees; average cost per total employees; total human resource cost per total employees; the human value add ratio; remuneration per revenue/total costs/profits; absence rate; and training cost per total number of employees.

\section{An overview of empirical research findings}

Delery and Doty (1996) draws on three dominant modes of theorising about strategic people management: the universalistic, contingency and configurational perspectives. The universalistic framework proposes that some people management practices are universally effective (Delery \& Doty, 1996; Delany \& Huselid, 1995; Huselid 1995; Pfeffer, 1998; Templer \& Hofmeyr, 1989). This means that organisations that adopt these best practices will reap the benefits of higher profits. The contingency framework proposes that the effectiveness of people management practices is contingent on the organisational strategy (Caligiuri \& Stroh, 1995; Huselid et al., 1997; Templer \& Cattnoe, 1991; Youndt et al., 1996). This means that organisations, which adopt human resource practices that are appropriate to its strategy, are more effective. The configuration framework proposes that the consistency within people management practices and strategies is necessary to enhance performance (Auther, 1994; Delery \& Doty, 1996; Dyer \& Reeves, 1995 Haynes \& Fryer, 2000; MacDuffie, 1995). This means that the bundling of people management practices into strategies will enhance organisational performance, which supports the research findings that high involvement, high performance, or high commitment management practices support the achievement of superior economic performance (Auther, 1994; Becker \& Gerhart, 1996; Delery \& Doty, 1996; Huselid, 1995; Huselid et al., 1997; Pfeffer, 1998; Welbourne \& Andrews, 1996; Youndt et al., 1996).

Notwithstanding these modes of theorising about effective people management, there appears to be little understanding of the processes required to realise this human potential or the specific conditions under which the human potential is realised. A major limitation of most of the past studies is the establishment of the causal relationship between people management and organisational performance. Table 1 provides a selected overview of strategic people management theories.

\section{Universalistic Approach}

This approach proposes that the adoption of universal people management best practices is more effective, i.e. produce superior organisational performance. The study conducted by Huselid et al. (1997) supports the contention that investments in people are a potential source of competitive advantage. The study found that technical human resource management practices such as recruitment; selection; performance measurement; training; and the administration of compensation and benefits have become institutionalised in United States firms. However, the study found no relationship between technical people management practice effectiveness and firm performance. Technical people management practice effectiveness is thus argued to be insufficient to produce a competitive advantage. However, the study confirmed the significant relationship between the strategic people management effectiveness and employee productivity, financial and market value. In spite of these results, they acknowledged that there were various conditions in the internal and external environment, which may have influenced both the people management activities and the firm's performance. Although the study included control measures in the statistical analyses, other causal models were still possible.
Delany and Huselid (1996) found a positive relationship between people management practices and the perception of firm performance. They used "perceived organisational performance" and "perceived market performance" to measure organisation performance. The results confirmed that progressive people management practices were positively related to perceptual measures of organisational performance.

Huselid, (1995) found that high performance work practices resulted in higher turnover $(7.05$ percent increase per employee), greater productivity ( $\$ 27,044$ more in sales) and corporate financial performance $(\$ 18,641$ more in market value and $\$ 3,814$ more in profits). Although Huselid concluded that the high impact of performance management practices on corporate financial performance was due to their influence on turnover and productivity, the source of the remaining gains was unclear.

In spite of the above studies, the nature of the alignment between effective people management and organisational performance, as a source of competitive advantage, remains unclear. A secondary objective of the study was thus to determine the effectiveness of the people management in the participating companies by comparing their people management with best practices.

\section{Contingency Approach}

This approach suggests that the alignment of people management with the appropriate strategy is more effective. Auther (1994) confirmed that strategy was significantly related to improved performance (34 percent fewer labour to produce a ton of steel) and better scrap rates (63 percent). Nonetheless, Auther was unable to test the fit between business strategy and people strategy. The study conducted by Schneider and Bowen (1985) found that service and people related organisational management practices were related to improved customers service quality in bank branches. Schmit and Allscheid (1995) demonstrated a relationship between employees' attitudes and customer satisfaction but were unable to explain the relationship between employee attitudes and profits. Youndt et al. (1996) supported the perspective that different types of people management strategies required different people management systems. They concluded that the link between people management and strategy required deeper understanding of how to manage people to improve competitiveness.

In an important longitudinal study conducted by Borucki (1989) the research design and conceptual model lent itself to expanding the conceptual approach to better understand the complex relationship between strategic people management and organisational performance. This research provided strong support for an emphasis on people management to drive organisational performance and goal attainment. It stressed the importance of people management to achieve strategic objectives. Accordingly, people management needs to support the implementation of the business strategy to leverage superior organisational performance.

According to Jackson and Schuler (1995) current literature does not fully consider the complexity of the model to describe the relationship between strategy and people management. The argument for internal and external fits remains compelling to understand the alignment between effective people management and business strategy. Another secondary objective of this study was to determine the nature of the alignment between effective people management and business strategy.

\section{Configuration Approach}

This approach suggests that organisations, which bundle people management into strategies, will be more effective. The study of nearly two hundred banks by Delery and Doty (1996) supports the notion that some configurations of people management 
TABLE 1

\section{STRATEgIC PEOPLE MANAGEMENT THEORIES}

\begin{tabular}{lll}
\hline Authors & $\begin{array}{c}\text { People Management } \\
\text { Perspective }\end{array}$ & \multicolumn{1}{c}{ Summary } \\
\hline Delany \& Huselid (1996) & Universalistic & $\begin{array}{l}\text { A positive relationship existed between human resource management practices and the perception of the } \\
\text { firms' performance. They used "perceived organisational performance" and "perceived market performance" } \\
\text { to measure organisation performance. This allowed Delany and Huselid to assess the impact of progressive } \\
\text { human resource practices on financial measures. }\end{array}$
\end{tabular}

Huselid (1995) Universalistic High performance work practices, which are one standard deviation above the mean are associated with lower turnover (7.05 percent decrease per employee), greater productivity (\$27,044 more in sales) and corporate financial performance $(\$ 18,641$ in more in market value and $\$ 3,814$ in profits).

Templer \& Hofmeyr Universalistic It is possible to predict effectiveness from the way human resources are managed, and this prediction holds (1989) $\quad$ across a wide range of organisations and a large number of employees.

Caliguiri \& Stoh (1995) Contingency/ This paper examined the relationship between mulinaional corporations' global management strategies Universalistic and the resulting international human resource practices. The HR practices vary by global strategies: ethnocentric; regiocentric; polycentric; and geocentric. These strategies were found to be related to economic variables (return on capital, sales growth, return on equity profit margin)

Templer \& Cattanoe Contingency (1991)

The research confirmed that a continuous process of what is happening to the organisation and where the business is going must inform the human resource strategy. HRM effectiveness is a function of the extent to which it adapts to the context and strategy within the organisation. Only through an HRM audit can it be demonstrated that the ultimate source of value is the people who work in the organisation. Human resource strategies must be concerned with the design and management of organisational processes of the business.

Huselid, Jackson \& Contingency The study focused on the impact of the overall Human Resource Management (HRM) quality on the firm's Schuler (1997) performance. The study found that the technical HRM effectiveness (i.e. recruitment, selection, performance measurement, training and the administration of compensation and benefits) were higher than the strategic HRM effectiveness. The results clearly indicated the extent to which technical HRM has become institutionalised in US firms. They found no relationship between the technical HRM effectiveness and the firms' performance. The study confirmed the significant relationship between the strategic people management effectiveness and employee productivity, financial and market value.

\begin{tabular}{lll}
\hline $\begin{array}{l}\text { Schneider \& Bowen } \\
(1985)\end{array}$ & Contingency & $\begin{array}{l}\text { Organisational management practices that are both services related and human resource provide cues that } \\
\text { customers use to evaluate service quality. }\end{array}$ \\
\hline Schmit \& Allscheid & $\begin{array}{l}\text { Contingency } \\
(1995)\end{array}$ & $\begin{array}{l}\text { Significant relationship was demonstrated between employees' attitudes, customer satisfaction and profits } \\
\text { in service firms. A less significant relationship existed between employee attitudes and profits in service } \\
\text { firms. }\end{array}$ \\
\hline Pfeffer (1998) & Contingency & $\begin{array}{l}\text { Numerous firms such as Singapore Airlines have succeeded financially by emphasising employee well-being } \\
\text { and customer service. }\end{array}$
\end{tabular}

Youndt, Snell, Dean Contingency Different types of people strategies (i.e. flexibility) require different people management systems.

Jr, \& Lepak (1996)

Borucki (1989) Contingency

Attempted to determine the impact and direction of the causality of strong financial performance on HR performance and effectiveness. The conceptual model lent itself to expanding the conceptual approach to understand the complex relationship between strategic human resources and organisational performance. This research provides strong support for an emphasis on human resources management to drive organisational performance and goal attainment. It emphasises the importance of people management to achieve strategic objectives.

Veldsman, Van der Linde Contingency

\& Conidaris, (1998)

The study found that the people management contribution to the success of South African companies is poor and needs to be renewed. The people management component in South African organisations was unable to support the business strategy to leverage strong organisational performance. There thus appear to be a misalignment of the people management and business strategies in South African organisations.

\begin{tabular}{ll}
\hline Haynes \& Fryer (2000) $\quad$ Configuration & $\begin{array}{l}\text { The ideal configuration of Human Resource Management policies and practices to a high quality strategy } \\
\text { will lead to a better understanding of the linkage between human resource management and service }\end{array}$
\end{tabular}
quality.

Delery \& Doty (1996) Configuration

This study of nearly two hundred banks suggests that some configurations of HR practices are better than other practices. They estimated that banks with a better configurations have nearly a 50 percent higher ROA and ROE than banks whose HR practices was just one standard deviation out of strategic alignment.

Dyer \& Reeves, (1995) Configuration The configurations of activities are considered more important in enhancing labour productivity than any single activity. Some human resource configurations are clearly better than others at enhancing labour productivity, controlling employee turnover, and improving product quality. This logic of bundling has inspired several attempts to build typologies of human resource strategies. It was concluded that there are solid theoretical reasons for firms to bundle their human resources activities into strategies.

MacDuffie (1995) Configuration Demonstrates a positive relationship between innovative human resource practices and economic performance. The overall evidence strongly supported the distinct bundling of human resource practices in an integrated system with the production/business strategy.

Pil \& MacDuffie (1996) Configuration

Found that the organisations' benefits from high involvement work arrangement increased with about 35 percent over five year period. One of the most interesting findings from the analysis was that the plants that most needed improvements were not more likely to adopt the best management practices to improve performance. 
practices are better than others. These banks had nearly 50 percent higher ROA and ROE than the banks whose human resource practices were just one standard deviation out of strategic alignment. This view supported the study conducted by Dyer and Reeves (1995), who found that the configurations of people management activities are considered more important in enhancing labour productivity than any other single activity. They argue that some people management configurations are clearly better than others at enhancing labour productivity, controlling employee turnover, and improving product quality. This logic of bundling has inspired several attempts to build typologies of people strategies (Dyer \& Reeves, 1995). There appear to be solid theoretical reasons for organisations to bundle their people management activities into strategies.

Similarly, the automobile assembly plants study conducted by MacDuffie (1995) demonstrated a positive relationship between innovative people management practices and economic performance. The overall evidence strongly supported the distinct bundling of people management practices in an integrated system with the business strategy (MacDuffie, 1995). These results provide strong statistical evidence of a positive relationship between innovative people management practices and economic performance. However, this study faced the dilemma of how to measure innovative people management practices. For example, some teams (or departments) may engage in more progressive people management practices than others. In a follow up study, Pil and MacDuffie (1996) found that organisations benefited from high involvement work arrangement. One of the most interesting findings from the research was that the assembly plants that most needed improvements were least likely to adopt the best management practices to improve performance. These organisations did not consider people as a critical component to improve performance and ultimately their competitive advantage.

Although the longitudinal study by Haynes and Fryer (2000) shed some light on the relationship between people management and performance, the alignment between effective people management bundles, business strategy and organisational performance still remains unclear (Auther, 1995; Borucki 1989; Delery \& Doty, 1996; Dyer \& Reeves, 1995; Huselid, 1995; Pfeffer, 1998; Veldsman et al., 1998). The final secondary objective of this study was to investigate the nature of the alignment between effective people management and organisational performance.

The critical question is: Is there an alignment between people management effectiveness, business strategy and the organisational performance in the South African banking and insurance sector? It is evident from the overview of empirical research that the magnitude and the direction of relationships are vague, and the complexity of relationships is also not fully understood. Therefore, it can be postulated that:

1. There is an alignment between effective people management and business strategy in the South African banking and insurance sector;

2. There is an alignment between effective people management and enhanced organisational performance in the South African banking and insurance sector and;

3. There is an alignment between effective people management business strategy and enhanced organisational performance in the South African banking and insurance sector.

\section{METHOD}

A field study was conducted to investigate the alignment between people management effectiveness, business strategy and organisational performance in the South African banking and insurance sector. Ambiguous interpretations of results are typical in non-experimental field studies, primarily because of a lack of control of extraneous variables (Mc Guigan, 1993). The variables in this type of research are often difficult to define, which complicates the control of the extraneous variables. Huselid et al. (1997) confirmed that a variety of conditions in the internal and external environment might influence both people management activities and the performance of the companies that present a source of extraneous variances. To reduce the effect on these variables, the study was conducted in a single industry to minimise the differences between companies in the different industries.

\section{Participating Organisations}

A sampling frame of twenty-seven banking and insurance companies was selected from the financial services sector listed on the Johannesburg Stock Exchange (JSE). These listed companies were selected to provide access to financial information. The questionnaires were sent to respondents via electronic mail to save cost and to minimise reply time. A response rate of $33 \%(\mathrm{~N}=9)$ was obtained after several follow-up electronic mail and telephonic attempts. The sample consisted of five banking companies and four insurance companies, which represent a total number of 89676 employees and total revenue of R59.6 billion. Human resource executives (50\%), senior managers $(25 \%)$, and middle managers $(25 \%)$ from the respective companies completed the questionnaires. Although the sample represents a significant proportion of the financial and insurance sector, the small size may result in the inflation of the error variance (i.e. measurement error). Consequently results need to be interpreted with caution.

\section{Measuring instruments}

A survey questionnaire was used to assess the alignment between people management effectiveness, business strategy and organisational performance. The Ernst and Young People Management Benchmarking Questionnaire (Veldsman et al., 1998) was adapted to assess business strategy and people management effectiveness. The questionnaire was designed to elicit information about how companies compare with best practice. The Saratoga Questionnaire (Saratoga Consulting and HRM Consulting, 1997) was adapted to assess organisational performance.

The research questionnaire consisted of six sections. The different sections elicited the following information of participating organisations: Section 1: Background information; Section 2: Business strategy; Section 3: Alignment and Strategic People Intent; Section 4: People Management Policies and Practices; Section 5: People Management Delivery Process; and Section 6: Organisational Performance. A four-point Likert-type scale was used for Sections 3 to 5 and in Section 6 the results from the most recent financial year of participating companies were obtained.

\section{Statistical analysis}

The data from the questionnaires was analysed by the Statistical Consulting Services of Rand Afrikaans University. Descriptive analyses were conducted. The calculations of frequencies, means and standard deviations were used to interpret the results from the study.

\section{RESULTS}

The following keys were used to interpret results: Mean scores of $1,0-2,9$ were defined as short of best practice (traditional practice); 3,0 - 3,9 as best practice; and a score of 4 as leading practice. The entrepreneurial and dynamic growth strategies were postulated to require leading and best people management approaches respectively, demanded typically by a high risk, rapid changing, ongoing renewing and externally focussed environment (Veldsman et al., 1998). The profit maintenance, turnaround and liquidation/divesture strategies were postulated to require traditional people management approaches, demanded typically by a low risk, stable, maintenance and internally focussed environment (Veldsman et al., 1998). 


\section{Business strategy}

The business strategy was assessed in terms of the following possible strategies: entrepreneurial; dynamic growth; profit maintenance; liquidation/divestiture; and turnaround strategies (Schuler, 1992). The results of the study indicated that $66 \%$ of the participants pursued a dynamic growth strategy; $11 \%$ a profit maintenance strategy; $11 \%$ an entrepreneurial strategy; and $11 \%$ a turnaround strategy (see Table 2). The majority (66\%) of participating companies were in line with best practice, pursuing a dynamic growth strategy.

TABle 2

BUSINESS STRATEGY SCORES

\begin{tabular}{lcc}
\hline Business Strategy & Frequency & Percent \\
\hline Entrepreneurial & 1 & $11 \%$ \\
Dynamic Growth & 6 & $67 \%$ \\
Profit maintenance & 1 & $11 \%$ \\
Turnaround & 1 & $11 \%$ \\
\hline
\end{tabular}

\begin{abstract}
Alignment of business and people strategies
Alignment was assessed in terms of all round participation in the generation of business and people strategies; joint ownership of such strategies; and setting up and maintenance of clear links in terms of content, process, execution and tracking between these strategies (Veldsman et al., 1998). The results of the study indicated that participating companies were slightly short of best practice on the alignment between the business and people management strategies in terms of participation $($ mean $=2,9$; S.D. $=0,6)$; joint ownership $($ mean $=$ $2,9$; S.D. $=0,6)$; but in line with best practice on clear links (mean $=3$; S.D. $=0,9)$. The overall alignment of business strategy and people management falls short of best practice $($ mean $=2,9 ;$ S.D. $=0,7)$
\end{abstract}

\section{Strategic People Intent}

Strategic people intent was assessed in terms of people philosophy, psychosocial contract and people profile. The results indicated that the overall strategic people intent (mean $=2,7$; S.D. $=0,6$ ) falls short of best practice (see Table 3 ).

The people philosophy was assessed in terms of: an ethical facet (How do we treat our people?); content facet (How do we view our people?); structure facet (How do we formalise the relationship with our people); process facet (How do we relate to our people?); and benefit facet (How must our people benefit from the relationship with our organisation?) (Veldsman et al., 1998). The results indicated that the companies were in line with best practice on the ethical facet (mean $=3,2$; S.D. $=0,7$ ); content facet ( mean $=3,0$; S.D. $=0,6)$; benefits facet $($ mean $=3,0$; S.D. $=0,9)$ but was short of best practice on the structure (mean $=2,9 ;$ S.D. $=0,6)$ and process facets (mean $=2,7 ;$ S.D. $=0,6)$. The overall People Philosophy (mean $=3,0 ;$ S.D. $=0,7$ ) was in line with best practice.

The psychosocial contract refers to the invisible and unwritten set of mutual expectations that evolve over time between the various parties who have an interest in the organisation (Veldsman et al., 1998). The psychosocial contract was short of best practice (mean $=2,4$; S.D. $=0,8$ ) with a strong partnership contract (mean $=2,9$; S.D. $=1,1)$, a lower presence of exchange contract (mean $=2,6 ;$ S.D. $=0,7)$ and an even weaker control contract (mean $=1,8 ;$ S.D. $=0,7$ ). The people profile assessed the organisation's picture of the ideal person to attract, deploy and retain (Veldsman et al., 1998). The overall people profile was just short of best practice (mean $=2,9$; S.D. $=0,6$ ).
People Policies and Practices

People policies and practices were assessed in terms of specific choices of interventions utilised by the participating organisations to manage their people (Veldsman et al.1998). The people management policies and practices were compared to 12 groupings of people management best practices. The overall people management policies and practices $($ mean $=2,8$; S.D. $=$ 0,8 ) were short of best practice.

TABLE 3

People management scores

\begin{tabular}{|c|c|c|}
\hline Dimensions & Mean & SD \\
\hline Overall Alignment & 2,9 & 0,7 \\
\hline Participation & 2,9 & 0,6 \\
\hline Joint ownership & 2,9 & 0,6 \\
\hline Clear links & 3,0 & 0,9 \\
\hline Overall People Strategic Intent & 2,7 & 0,6 \\
\hline Overall People Philosophy & 3,0 & 0,7 \\
\hline Ethics & 3,2 & 0,7 \\
\hline Content & 3,0 & 0,6 \\
\hline Structure & 2,9 & 0,6 \\
\hline Process & 2,7 & 0,6 \\
\hline Benefit & 3,0 & 0,9 \\
\hline Overall Psycho-social Contract & 2,4 & 0,8 \\
\hline Exchange contract & 2,6 & 0,7 \\
\hline Partnership contract & 2,9 & 1,1 \\
\hline Control contract & 1,8 & 0,7 \\
\hline Overall People Profile & 2,9 & 0,6 \\
\hline Overall People Management Policies and Practices & s 2,8 & 0,8 \\
\hline Human Resource Needs Planning & 2,3 & 0,7 \\
\hline Conditions of Service & 2,8 & 0,8 \\
\hline Design of Work and organisation & 2,7 & 1,0 \\
\hline Recruitment and Selection & 2,8 & 0,8 \\
\hline Induction & 3,0 & 1,0 \\
\hline Performance Management & 3,2 & 0,7 \\
\hline Training and Development & 3,0 & 0,7 \\
\hline Reward and Recognition & 3,0 & 0,5 \\
\hline Employee Well-being & 2,4 & 0,9 \\
\hline Relation Management & 2,8 & 0,8 \\
\hline Community Involvement/Social Responsibility & 3,2 & 0,7 \\
\hline HR Information/Administration & 2,7 & 0,9 \\
\hline Overall People management Service Delivery & 2,6 & 0,7 \\
\hline Delivery paradigm & 2,9 & 1,0 \\
\hline Delivery position & 2,6 & 1,0 \\
\hline HR Roles & 2,8 & 0,7 \\
\hline HR Delivery Style & 2,0 & 0 \\
\hline
\end{tabular}

The results indicated that companies were in line with best practice with regard to induction (mean $=3,0$; S.D. $=1,0$ ); performance management (mean $=3,2$; S.D. $=0,7$ ); training and development $($ mean $=3,0$; S.D. $=0,7)$; reward and recognition (mean $=3,0$; S.D. $=0,5)$; and community involvement/social responsibility (mean $=$ 3,$2 ;$ S.D. $=0,7$ ) practices. The aforementioned policies and practices may be bundled as development and retaining practices.

However, more traditional policies and practices were followed with regard to human resource needs planning (mean $=2,3$; S.D. $=$ $0,7)$; design of work and organisation (mean $=2,7$; S.D. $=1,0$ ); conditions of service (mean $=2,8$; S.D. $=0,8$ ); recruitment and selection (mean $=2,8$; S.D. $=0,8$ ); employee well-being ( mean $=2,4$; S.D. $=0,9)$; relationship management $($ mean $=2,8 ;$ S.D. $=0,8)$; and human resource information and administration (mean $=2,7$; S.D. $=0,9)$. These policies and practices may be bundled as attracting, placing and building commitment policies and practices. 


\section{People delivery process}

The people delivery process was assessed in terms of four elements, namely: the paradigm underlying the delivery process; the positioning of the delivery process; the delivery roles; and the style of delivery (Veldsman et al., 1998). The overall people delivery process was short of best practice (mean $=2,6 ;$ S.D. $=0,7$ )

The people management delivery paradigm was just short of best practice $($ mean $=2,9$; S.D. $=1,0)$ with a preferred short term, operational time perspective but in line with best practice with regards to an integrated service delivery function. The positioning of the delivery process was short of best practice (mean $=2,6 ;$ S.D. $=1,0$ ) with a specialist driven disciplinary base positioned remotely from business clients.

The people management delivery role was short of best practice (mean $=2,8 ;$ S.D. $=0,7)$ with a stronger people champion, strategic partner and change agent role, and a weaker administrative role. The results indicated that the people management delivery styles were more traditional (mean $=2,0$; S.D. $=0$ ) with strong joint decision-maker, expert and advocate styles. This delivery style focused on the direct involvement of professionals with a strong task orientation towards the delivery of people management interventions.

The overall people management fall short of best practices and was therefore misaligned with the dynamic growth strategy, which requires progressive people practices i.e. best practices.

Organisational Performance: Financial, Organisational and People Measurements

\section{TABLE 4}

FinANCIAL OUTCOMES SCORES

\begin{tabular}{lc}
\hline \multicolumn{1}{c}{ Dimensions } & Figures \\
\hline Revenue & R6.6 billion \\
Expenses & R3.6 billion \\
Efficiency ratio & $53.7 \%$ \\
Profit after tax & $\mathrm{R} 2.1$ billion \\
\hline
\end{tabular}

Table 4 shows that the mean revenue of the participating companies amounted to R6.6 billion; mean operating expenses to R3.6 billion; and mean profit after tax to R2.1 billion. The results from one of the participants were excluded because the company is a non-profit government organisation and therefore incomparable. Mean profit after tax of R2.1 billion falls short of the industry standard of R7.0 billion for 1999. The efficiency of the financial services sector was determined by expressing operating expenses as a percentage of total income, i.e. cost-toincome ratios. The overall efficiency ratio (mean $=53,7 \%$; S.D. $=22.2 \%$ ) was better than best practice (i.e. a 60 per cent efficiency ratio).

TABLE 5

ORgANISATIONAL OUTCOME SCORES

\begin{tabular}{lcc}
\hline Dimensions & Mean & SD \\
\hline Overall Organisation outcomes & 3,1 & 0,5 \\
Service quality & 2,9 & 0,3 \\
Product quality & 3,6 & 0,5 \\
Customer satisfaction & 2,8 & 0,4 \\
New product development & 3,2 & 0,4 \\
\hline
\end{tabular}

The results also indicated that the participating companies were in line with best practice (mean $=3,1$; S.D. $=0,5$ ) on overall organisational outcomes (see Table 5). The participating companies perceived themselves to be in line with best practice on product quality $($ mean $=3,6 ;$ S.D. $=0,5)$ and new product development (mean $=3,2$; S.D. $=0,4)$ but were short of best practice on service quality (mean $=2,9 ;$ S.D. $=0,3$ ) and customer satisfaction $($ mean $=2,8 ;$ S.D. $=0,4)$

The average number of employees (headcount) of the participating companies was 9964 employees. The average revenue per employee was R598 153; the average expense per employees was R327 592; and the average profit per employees was R187 406 (see Table 6). The profits fall short of industry standards and therefore these results may also be interpreted as short of best practice. The people management of participating companies fell short of best practice and was therefore unable to produce enhanced organisational performance, which was in line with industry standard. However, a variety of conditions in the internal and external environment of the participating organisations may have had an influence on both the people management and organisational performance.

TABLE 6

PEOPLE MANAGEMENT OUTCOME SCORES

\begin{tabular}{lc}
\hline \multicolumn{1}{c}{ Dimensions } & Figures \\
\hline Average revenue per total employees & R598 153.00 \\
Average expense per total employees & R327 592.00 \\
Average profit per total employees & R187 406.00. \\
\hline
\end{tabular}

\section{DISCUSSION}

The powerful trends changing the face of the financial industry will accelerate as South Africa enters the 21st century (South African Banking Review, 1999). These trends create the setting in which South African banking and insurance companies need to formulate their strategic people intent.

Due to the small sample size, the error variance (measurement error) could have been inflated and consequently the results must be interpreted with caution. Caution also needs to be taken when generalising the findings reported in this study to the overall financial services industry in South Africa.

TABLE 7

OVERALL FINDINGS

\begin{tabular}{|c|c|c|c|}
\hline Dimensions & $\begin{array}{l}\text { Short of Best } \\
\text { Practices }\end{array}$ & Best Practices & $\begin{array}{l}\text { Leading } \\
\text { Practices }\end{array}$ \\
\hline $\begin{array}{l}\text { Dominant Business } \\
\text { Strategy }\end{array}$ & & $\begin{array}{l}\text { Dynamic } \\
\text { Growth }\end{array}$ & \\
\hline $\begin{array}{l}\text { Alignment of Business and } \\
\text { People Strategies }\end{array}$ & 2,9 & & \\
\hline \multicolumn{4}{|l|}{ Strategic People Intent } \\
\hline Philosophy & & 3,0 & \\
\hline Psycho-social Contract & 2,4 & & \\
\hline Profile & 2,7 & & \\
\hline $\begin{array}{l}\text { People Management Policy } \\
\text { and Practices }\end{array}$ & 2,8 & & \\
\hline People Delivery Process & 2,8 & & \\
\hline Organisational Performance & $\mathrm{X}$ & & \\
\hline
\end{tabular}


It is evident from the results that the majority of the participating companies are in pursuit of a dynamic growth strategy. These companies generally expand through the development of products and services within set parameters and guidelines. This supported the findings that participating companies were in line with best practice on product quality and new product development. There appears to be little or no alignment between business and people strategies in participating companies. This misalignment may be ascribed to the low levels of participation and ownership of these strategies in these companies. In spite of this, there were clear links between the business strategies and people strategies in terms of the content, process, execution and tracking of these strategies. Although there is limited participation and ownership by all employees in the strategy formulation, the people philosophy (i.e. thinking) is closely linked to business objectives.

However, the true indicator of a people philosophy is portrayed in the actual people management policies and practices pursued. The operationalisation of people philosophy into people practices and delivery falls short of best practice. The participating companies seem to pursue low involvement, low commitment people management policies and practices, with a strong focus on developing and retaining people. The typical people management policies associated with these practices included induction; performance management; training and development; reward and recognition; and community involvement/social responsibility. It seems that less emphasis is placed on attracting, placing and building the commitment of people. The policies associated with these practices include conditions of services; human resource needs planning; recruitment and selection (attract); design of work and organisation (placement); employee well-being; and relationship management (commitment).

In the war for talent, the participating companies appear to focus on retaining and developing internal candidates, but neglect the attraction and placement of new skills. This focus may be ascribed to the shortage of skills in the South African labour market. The low commitment practices may be based on the past antagonistic relationship between management and employees. However, increasingly, this situation within the employee relation's arena is changing towards building economic empowerment, as opposed to the traditional struggle for worker rights. The increasing shareholding of unions in multinational businesses is an indication of the times. Human resource information and administration practices were also lagging behind best practice and appear unable to support people management policies and practices. These findings appear to support the solid theoretical reason of bundling people management activities into appropriate strategies (Auther, 1994; Delery \& Doty 1996; Dyer \& Reeves, 1995; Haynes \& Fryer, 2000; MacDuffie, 1995).

The people service delivery of the participating companies focused on a short term, operational time perspective with an external focus on business needs and priorities. Although people delivery focused on direct involvement in the business needs and priorities, the remote location of the people management delivery may result in inadequate servicing of people and line managment. The alignment between the people delivery process and people management policies and practices may support the actualisation of the strategic people intent, but is insufficient to support the realisation of a dynamic growth business strategy. These results support the contention that people management, which is aligned with the appropriate business strategy is more effective and critical for the achievement of business objectives (Caligiuri \& Stroh, 1995; Huselid et al., 1997; Schuler \& Jackson, 1995; Templer \& Cattanoe, 1991; Youndt et al., 1996; Veldsman et al., 1998).

To conclude, the people management policies, practices and delivery of participating companies in this study were misaligned with the dynamic growth strategy and thus unable to sufficiently unleash the contribution of people to business success.

Mean profit after tax fell short of industry standards. According to The South African Banking Review (1999), this decline in profitability was a common phenomenon in the South African financial services industry and throughout the world. The financial service industry's response to these trends was manifested in a reduction of costs and an increase in revenue to maintain a satisfactory level of return on equity (Ibid). The latter is apparent in the high efficiency ratios of participating companies. The traditional approach to people management followed by the majority of participating may be a contributing factor to the poor results reported on the service quality and customer satisfaction. However, the performance data from the study was insufficient to conclusively determine the effects of an alignment between effective people management, business strategy and organisational performance.

In the competitive financial industry, people need to be a differentiating factor to achieve superior organisational performance. This everlasting debate must be put to rest and the banking and insurance industry must focus on leveraging people to produce a desired level of performance. Companies in this sector need to improve the level of participation of all employees in their strategy formulation, and to develop commitment and ownership to the business objectives. They must achieve both the internal and external alignment of their people management strategies in order to enable the achievement of the desired organisational performance. Furthermore, the configuration of people management practices of participating companies must be internally aligned to encourage the achievement of personal, and ultimately organisational objectives.

The front-end service delivery process needs to be in the immediate vicinity of their clients to ensure an appropriate business context and efficient service delivery. The back-end of the delivery process requires being centralised in a consulting or shared services mode. The people management professionals should play a critical role as strategic business partners with a long-term, strategic perspective and a strong customer orientation. This role needs to be balanced with a strong expert people champion role to support employee needs.

To reduce the effect of extraneous variables, the study was conducted in a single industry. The sample consisted of financial services sector companies listed on the Johannesburg Stock Exchange to ensure access to financial information. This limited the study to small sample of companies in the banking and insurance sector. The small sample size thus made the determination of the statistical significant relationship between people management and business strategy impossible. The questionnaires were also completed by representatives of the organisations, i.e. human resource directors and managers, and may not necessarily reflect the opinion of the whole organisation. The organisational performance data was incomplete and therefore incomparable. As a result of these limitations, caution needs to taken in making generalisations about the findings with reference to the financial services industry.

Although the magnitude and the direction of the relationships are still unclear, an opportunity exists for further longitudinal research to determine the effect of the alignment between effective people management, business strategy and organisational performance.

\section{REFERENCES}

Auther, J.B. (1994). Effects of human resources systems on manufacturing performance and turnover. Academy of Management Journal, 37 (3), 670-687. 
Becker, B. \& Gerhart, B. (1996). The impact of human resource management on organisational performance: Progress and prospects. Academy of Management Journal, 39 (4), 779-801.

Borucki, C.C. (1989). Strategic human resource management, organisational effectiveness and organisational performance: a longitudinal case study. UMI Dissertation Information Service, University Microfilms International, A Bell \& Howell Information Company, PhD. D, The University of Michigan.

Caliguiri, P.M. and Stroh, L.K. (1995). Multinational corporation management strategies and international human resources practice: Bringing IHRM to the bottom line. International Journal of Human Resource Management, 6 (3), 494-504.

Delery, J.E. and Doty, D.H. (1996). Models of theorizing in strategic human resource management, manufacturing strategy, and firm performance, Academy of Management Journal, 39 (4), 836-866.

Delany, J.T. \& Huselid, M.A. (1996). The impact of human resource management practices on the perception of organisational performance, Academy of Management Journal, 39 (4), 949-969.

Drago, W.A. (1990). Strategic management and the search for determinants of organisational effectiveness, UMI Dissertation Information Service, University Microfilms International, A Bell \& Howell Information Company. Ph.D., University of Arkansas.

Dyer, L. and Reeves, T. (1995). Human resource strategies and firm performance: what do we know and where do we need to go? The International Journal of Human Resource Management, 6 (3), 656-669

Ferguson, G. A. \& Takanane, Y. (1989). Statistical analysis in psychology and education, $6^{\text {th }}$ ed. New York: USA, McGrawHill International Edition.

Haynes, P. \& Fryer, G. (2000). Human resources, service quality and performance: a case study. International Journal of Contemporary Hospitality Management, 12 (4), 0959-6119.

Huselid, M.A. (1996). The impact of human resource management practices on turnover productivity and corporate financial performance, Academy of Management Journal, 38 (3), 635-672.

Huselid, M.A. \& Becker, B.E. (1996). Methodological issues in cross-sectional and panel estimates of the human resourcefirm performance link, Industrial Relations, 35 (3), 400-421.

Huselid, M. A. Jackson, S.E. \& Schuler, R.S. (1997). Technical and strategic human resource management effectiveness as determinants of firm performance. Academy of Management Journal, 40 (1), 171-188.

Jackson, S.E. \& Schuler, R.S. (1995). Understanding Human resource management in the context of organisations and their environment. Annual Review of Psychology, 46, 237-264.

MacDuffie, J.P. (1995). Human resource bundles and manufacturing performance: organisational logic and flexible production systems in world auto industries, Industrial and Labor Relations Review, 48 (2), 199.
Pil, F.K. \& MacDuffie, J.P. (1996). The adoption of highinvolvement work practices, Industrial and Labor Relations Review, 35 (3), 105.

Mc Guigan, F.J. (1993). Experimental Psychology: Methods of Research $\left(6^{\text {th }}\right.$ ed). Englewood Cliffs, New Jersey: Prentice Hall.

Pfeffer, J. (1998). The human equation: Building profits by putting people first. Boston, Massachusetts: Harvard Business School Press.

Snell, S.A. \& Youndt, M.A. (1995). Human resource management and firm performance: Testing a contingency model of executive controls. Journal of Management, 21 (4), 711-737

Saratoga Consulting (SA), \& HRM Consulting Structure of the HR function, (1997). An International Study, Focus on HR practice in South Africa, 4-102

Schmit, M.J. \& Allscheid, S.P. (1995). Employee attitudes and customer satisfaction: making theoretical and empirical connections, Personnel Psychology, 48, 521-536.

Schneider, B. \& Bowen, D. E. (1985). Employee and customer perceptions of service in banking: replication and extensions, Journal of Applied Psychology, 70, (3) 431.

Schuler, R.S. (1992). Strategic human resource management: Linking the people with the strategic need of the business. Organisational Dynamics, 21 (1), 18-32.

Templer, A. \& Cattanoe, J. (1991). Assessing Human Resource Management effectiveness: How much have we learned? South African Journal of Labour Relations, 15 (4), 23-30.

Templer, A.J. \& Hofmeyr, K.B. (1989). A national investigation of the correlation between perceptions of human resources management practices and organisational effectiveness. South African Journal of Business Management, 20 (1), 7-12

The South African Banking Review. (1998). The Banking Council: South Africa.

The South African Banking Review. (1999). The Banking Council: South Africa.

Ulrich, D. (1997). Human Resource Champions: The next agenda for adding value and delivering results. Boston, Massachusetts: Harvard Business School of Press.

Van Gorp, S. Hall, K. Keene, A. Holden, T. \& Soh, M. (1997). Managing the Value Network: Spotlight on Australia. Sixth Annual International Technology in Banking Survey, Ernst \& Young.

Veldsman, T.H., van der Linde, A. \& Conidaris, C. (1998). Benchmarking Study of People Management in South African companies. Johannesburg, South Africa: Ernst \& Young, People Effectiveness Group.

Welbourne, T. and Andrews, A. (1996). Predicting Performance of Initial Public Offering firms: Should HRM be in the Equation? Academy of Management Journal, 39 (4), 891-919.

Youndt, M.A. Snell, S.A. Dean Jr, J.W. Lepak, D.P. (1996). Human resource management, manufacturing strategy, and firm performance, Academy of Management Journal, 39 (4), 836-866. 